\title{
The National Flood-Frequency Program-Methods for Estimating Flood Magnitude and Frequency in Connecticut, 2001
}

\section{Introduction}

Estimates of the magnitude and frequency of flood-peak discharges and flood hydrographs are used for a variety of purposes, such as for the design of bridges, culverts, and flood-control structures; and for the management and regulation of flood plains. To provide simple methods of estimating flood-peak discharges, the U.S. Geological Survey (USGS) has developed and published regression equations for every State, the Commonwealth of Puerto Rico, American Samoa, and a number of metropolitan areas in the United States. In 1993, the USGS, in cooperation with the Federal Emergency Management Agency and the Federal Highway Administration, compiled all current USGS statewide and metropolitan area regression equations into a computer program, titled "The National Flood-Frequency (NFF) Program" (Jennings and others, 1994).

Since 1993, new or updated equations have been developed by the USGS for various areas of the Nation. These new equations have been incorporated into an updated version of the NFF Program.

This Fact Sheet describes the application of the updated NFF Program to streams in Connecticut. Information on obtaining the NFF software and fact sheets for other areas of the Nation is provided at the end of this Fact Sheet.

\section{Overview}

Weiss (1983) developed regression equations for estimating peak discharges $\left(\mathrm{Q}_{\mathrm{T}}\right)$, in cubic feet per second, for selected recurrence intervals $(\mathrm{T})$ ranging from 2 to 100 years for ungaged, unregulated, rural basins in Connecticut (a) having drainage areas greater than or equal to 100 square miles, (b) having drainage areas greater than or equal to 10 square miles and less than 100 square miles, (c) having drainage areas less than 10 square miles, and (d) having all drainage areas. Weiss (1983), however, recommended that only the regression equations developed for use with all drainage areas be used to estimate peak discharges for ungaged sites because the numbers of stations used to develop the other equations were too small to provide confidence in the estimates obtained from them. The equations for all drainage areas can be used statewide in basins where the area that is impervious or that is drained by storm sewers accounts for less than 10 percent of the basin area. Data from 96 streamgaging stations were used by Weiss (1983) to develop the regression equations for all drainage areas.

Recurrence interval is the reciprocal of the annual exceedance probability, and represents the average number of years between peak discharges of the same or greater magnitude. For example, the 100year flood occurs, on average, once in 100 years, and has a 0.01 exceedance probability. This does not imply that the 100 -year flood will be exceeded each 100 years, but that it has a 1-percent probability of occurring in any given year.

A current (2001) study by the USGS is incorporating new geographic information systems, digital map data,

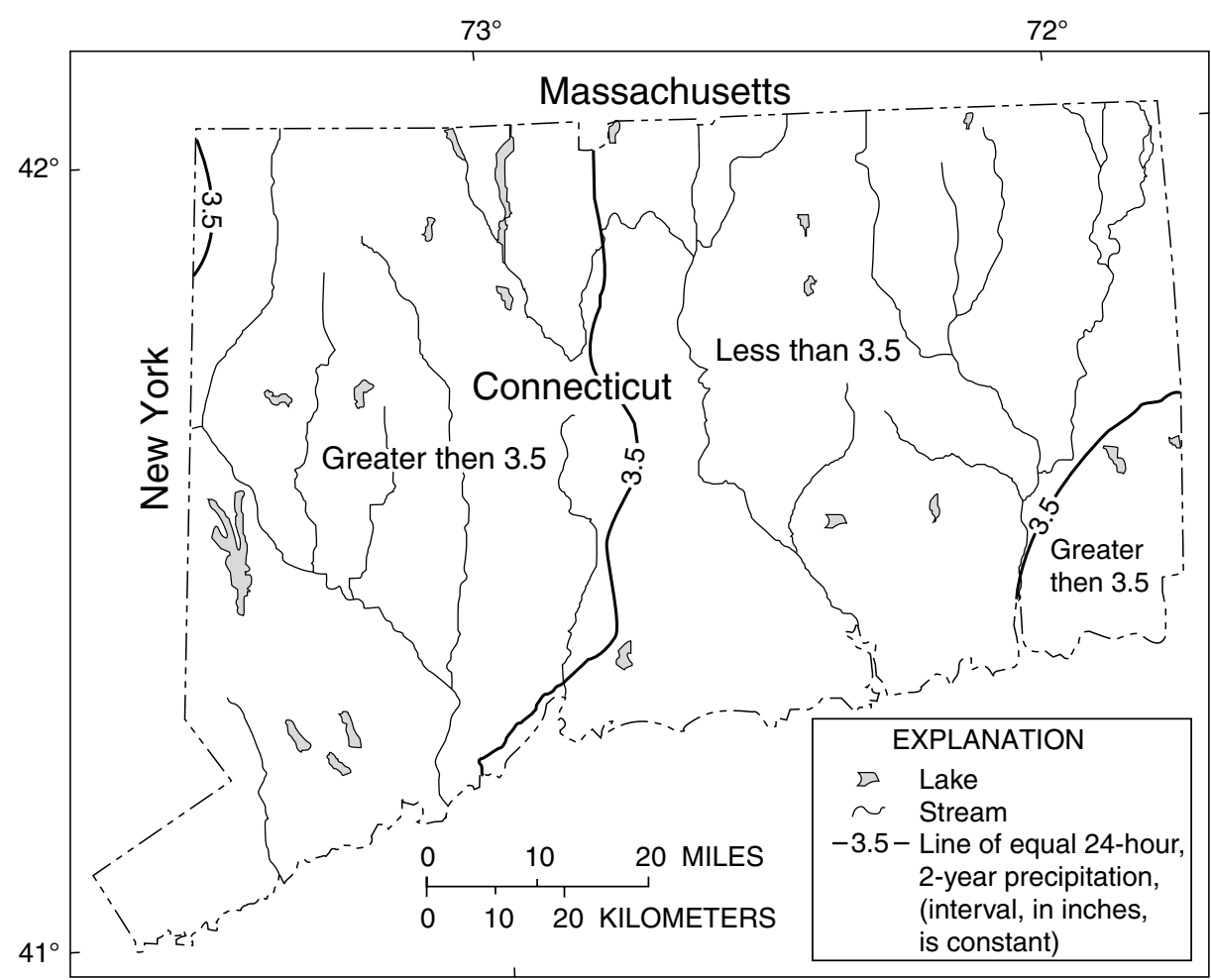

Figure 1. Distribution of 24-hour, 2-year rainfall for the State of Connecticut. (Weiss, 1975) 
updated guidelines for computing floodfrequency curves, and new statistical methods to develop new regionalization regression equations for use in estimating peak discharges for ungaged sites in Connecticut. The study is being done in cooperation with the Connecticut Department of Transportation and the Connecticut Department of Environmental Protection.

\section{Procedure}

The equations developed by Weiss (1983) for all drainage areas are in the inch-pound system of units, however, the NFF program will accept and report either the inch-pound or the metric system of units.

The watershed and climatic variables used in the regression equations are as follows:

Drainage area (A), in square miles, obtained from 1:24,000 scale USGS topographic maps.

24-hour rainfall for recurrence interval $\mathrm{T}$ $\left(\mathrm{I}_{\mathrm{T}}\right)$, in inches, obtained from maps found in Weiss (1975) and reproduced in this Fact Sheet (figs. 1-5).

Main channel stream length (L), in miles, obtained from 1:24,000 scale USGS topographic maps.

Main channel slope $\left(S_{m}\right)$, in feet per mile, obtained from 1:24,000 scale USGS topographic maps by extending the stream to the drainage divide and computing the slope of the main channel between 10 and 85 percent of the distance from the ungaged site to the drainage divide (Benson, 1962, p. B23-B25).

Area of coarse-grained stratified drift $\left(\mathrm{A}_{\mathrm{sd}}\right)$, in percent, obtained from 1:24,000 scale maps of surficial geology (Henney, 1981). The NFF program adds the constant of 1 to the input value of $\mathrm{A}_{\mathrm{sd}}$; the user should enter the actual value.

The regression equations and the standard errors of estimate are shown in table 1 . The average standard error of estimate is a measure of the goodness of fit between the equation and the data used to derive the equation. Errors in the $Q_{T}$
Table 1. Peak-flow regression equations and standard errors of estimate for streams that drain rural areas of Connecticut (modified from Weiss, 1983)

$\left[\mathrm{Q}_{\mathrm{T}}\right.$, peak flow for recurrence interval T, 2 to 100 years, in cubic feet per second; A, drainage area, in square miles; $\mathrm{I}_{\mathrm{T}}$, rainfall in 24 hours for recurrence interval $\mathrm{T}$, in inches; $\mathrm{L}$, main channel stream length, in miles; $\mathrm{S}_{\mathrm{m}}$, main-channel slope, in feet per mile; $\mathrm{A}_{\mathrm{sd}}$, area of coarse-grained stratified drift, in percent]

\section{Regression equation}

Standard error of estimate, in percent

$$
\begin{aligned}
& Q_{2}=7.6 A^{0.97}\left(I_{2}\right)^{2.0}\left(\frac{L}{\sqrt{S_{m}}}\right)^{-0.17}\left(A_{s d}+1\right)^{-0.2} \\
& Q_{10}=6.6 A^{1.0}\left(I_{10}\right) 1.89\left(\frac{L}{\sqrt{S_{m}}}\right)^{-0.22}\left(A_{s d}+1\right)^{-0.19} \\
& Q_{25}=21.2 A^{1.0}\left(I_{25}\right) 1.21\left(\frac{L}{\sqrt{S_{m}}}\right)^{-0.23}\left(A_{s d}+1\right)^{-0.20} \\
& Q_{50}=23.2 A^{1.03}\left(I_{50}\right) 1.14\left(\frac{L}{\sqrt{S_{m}}}\right)^{-0.26}\left(A_{s d}+1\right)^{-0.20} \\
& Q_{100}=28.7 A_{\left(I_{100}\right)}^{1.08}\left(\frac{L}{\sqrt{S_{m}}}\right)^{-0.27}\left(A_{s d}+1\right)^{-0.22}
\end{aligned}
$$

$\pm 36.7$

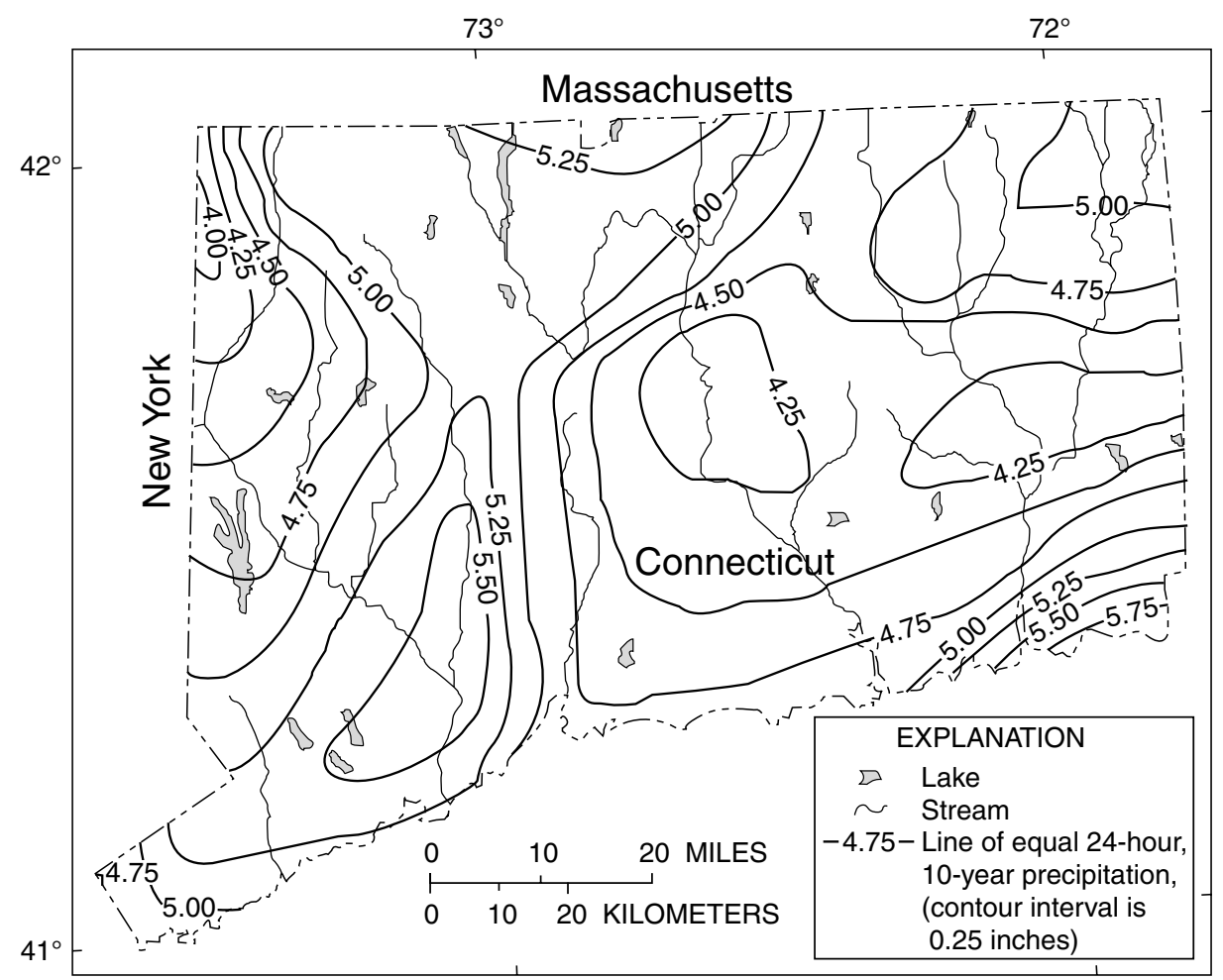

Figure 2. Distribution of 24-hour, 10-year rainfall for the State of Connecticut. (Weiss, 1975) 


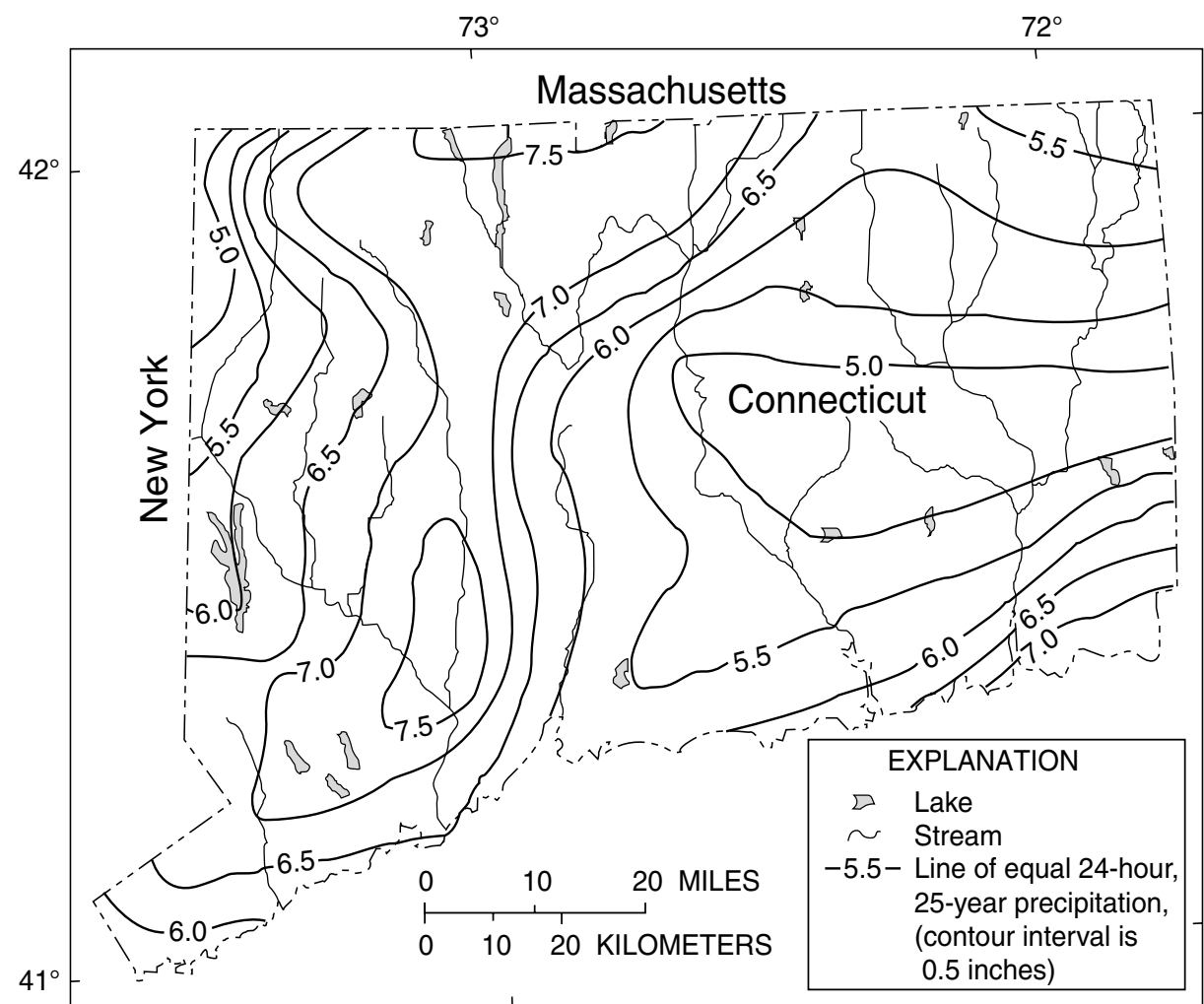

Figure 3. Distribution of 24-hour, 25-year rainfall for the State of Connecticut. (Weiss, 1975)

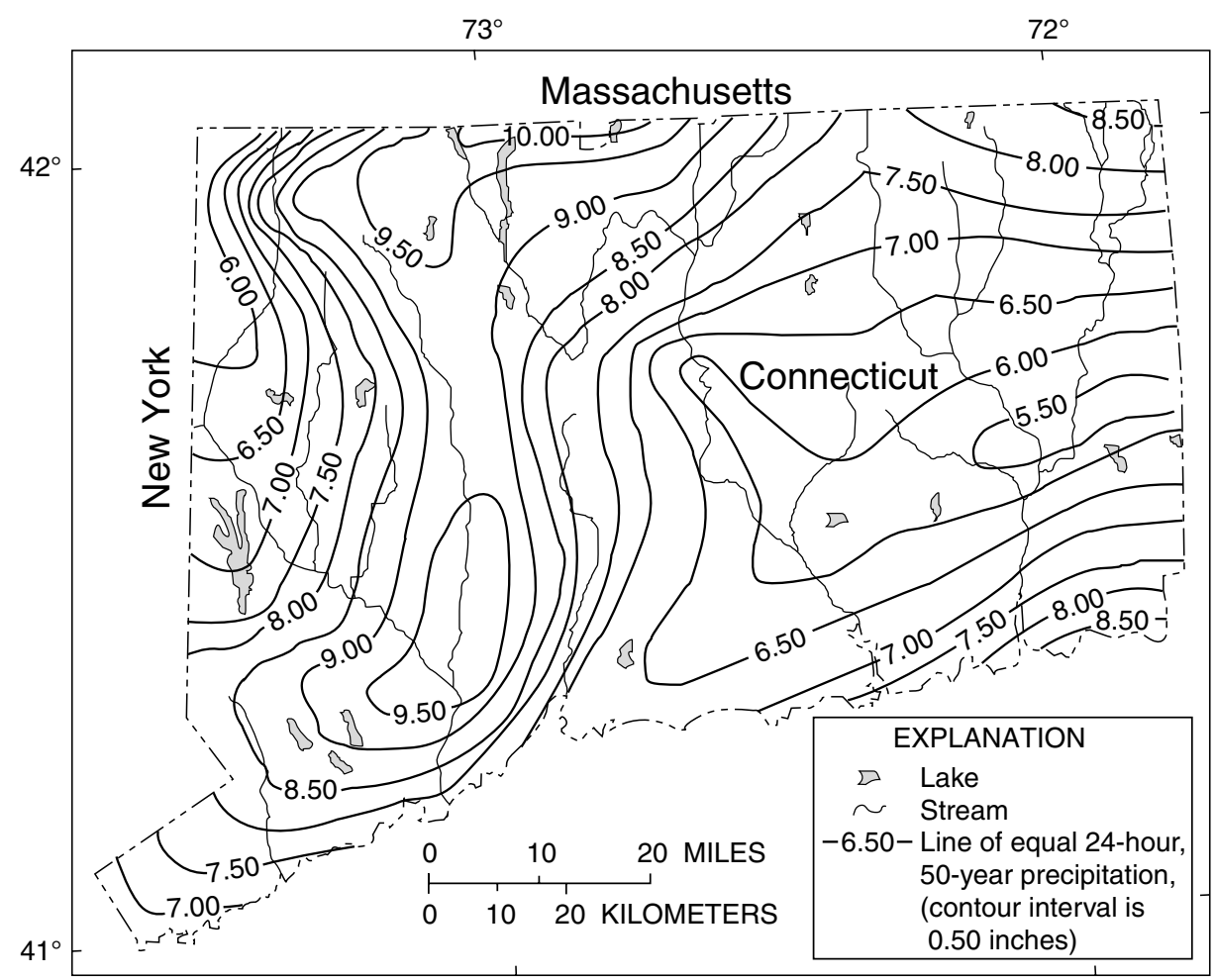

Figure 4. Distribution of 24-hour, 50-year rainfall for the State of Connecticut. (Weiss, 1975) estimates for about two thirds of the stations used in the regression analyses were within the given standard errors. Errors in the $Q_{T}$ estimates for ungaged sites are somewhat larger than the standard errors of estimate shown in table 1. Errors increase appreciably when any of the basin characteristics used in the equations are near or beyond the range limits shown in table 2 .

Table 2. Range of explanatory variables for which regression equations are applicable in Connecticut

[A, drainage area, in square miles; $\mathrm{I}_{\mathrm{T}}, 24$-hour rainfall for recurrence interval $\mathrm{T}$, in inches; $\mathrm{L}$, main channel stream length, in miles; $S_{m}$, main channel slope, in feet per mile; $A_{\mathrm{sd}}$, area of coarse-grained stratified drift, in percent]

\begin{tabular}{cc}
\hline Variable & Range \\
\hline $\mathrm{A}$ & $0.36-1,541$ \\
$\mathrm{I}_{2}$ & $2.4-3.05$ \\
$\mathrm{I}_{10}$ & $4.2-5.6$ \\
$\mathrm{I}_{25}$ & $5.0-7.5$ \\
$\mathrm{I}_{50}$ & $5.6-10.1$ \\
$\mathrm{I}_{100}$ & $6.2-12.5$ \\
$\mathrm{~L}$ & $0.7-140$ \\
$\mathrm{~S}_{\mathrm{m}}$ & $6-294$ \\
$\mathrm{~A}_{\mathrm{sd}}$ & $0-67.1$ \\
\hline
\end{tabular}

\section{—Prepared by Steve S. Sumioka}

\section{References}

Benson, M.A. 1962, Factors influencing the occurrence of floods in a humid region of diverse terrain: U.S. Geological Survey Water-Supply Paper 1580B, 64 p..

Henney, L.H., comp., 1981, Natural resources information directory for the State of Connecticut: Connecticut Department of Environmental Protection, $39 \mathrm{p}$.

Jennings, M.E., Thomas, W.O., Jr., and Riggs, H.C., comps., 1994, Nationwide summary of U.S. Geological Survey regional regression equations for estimating magnitude and frequency of floods for ungaged sites, 1993: U.S. Geological Survey WaterResources Investigations Report 944002, 196 p. 


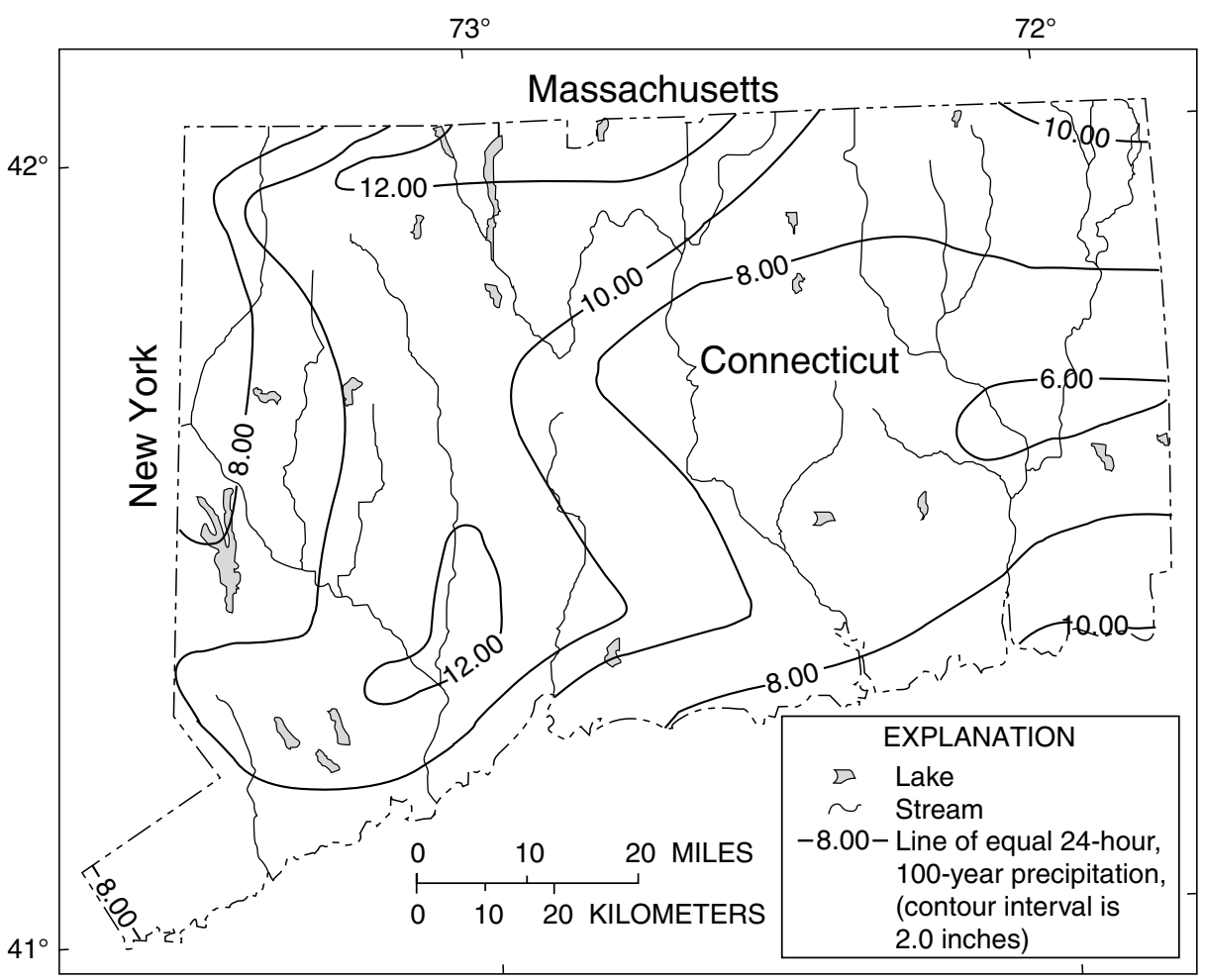

Figure 5. Distribution of 24-hour, 100-year rainfall for the State of Connecticut. (Weiss, 1975)
Weiss, L.A., 1975, Flood flow formulas for urbanized and nonurbanized areas of Connecticut: Watershed and Management Symposium, Logan, Utah, Irrigation and Drainage Division, American Society of Civil Engineers, p. 658-675.

1983, Evaluation and design of a streamflow-data network for Connecticut: Connecticut Water Resources Bulletin No. 36, 30 p.

For more information contact:

U.S. Geological Survey

Office of Surface Water

415 National Center

Reston, Virginia 20192

(703) 648-5301

USGS hydrologic analysis software is available for electronic retrieval through the World Wide Web (WWW) at http://water.usgs.gov/software/ and through anonymous File Transfer Protocol (FTP) from water.usgs.gov (directory: /pub/software). The WWW page and anonymous FTP directory from which the National Flood-Frequency software and user documentation can be retrieved are http://water.usgs.gov/software/nff.html and /pub/software/surface_water/nff, respectively.

Additional earth science information is available from the USGS through the WWW at http://www.usgs.gov/ or by calling 1-888-ASK-USGS. 